\title{
Synthesis of Ene-ynamide Derivatives Starting from Baylis-Hillman Adducts: Isomerization with the Aid of $\pi$-Cation Interaction
}

\author{
Saravanan Gowrisankar, Ka Young Lee, Seung Chan Kim, and Jae Nyoung Kim* \\ Department of Chemistry and Institute of Basic Science, Chonnam National University, Gwangju 500-757, Korea \\ *E-mail:kimjn@chonnam.ac.kr \\ Received June 3, 2005
}

Key Words : Ene-ynamides, Baylis-Hillman adducts, $\pi$-Cation interaction

Recently, we have developed a facile synthetic method of 9-phenyl-7H-benzocycloheptene derivatives from the alkynyl moiety-containing Baylis-Hillman adducts, which involved intramolecular Friedel-Crafts alkenylation reaction of triple bond-tethered methyl cinnamates. ${ }^{1}$ We also reported the synthesis of iodoenol lactones from the same substrates via the typical iodolactonization protocol. $^{2}$ During the investigation we envisaged that we could prepare the corresponding lactam derivatives from the acetates of the Baylis-Hillman adducts by using similar strategy as shown in Scheme 1.,4 However, during the investigation for the synthesis of lactam derivatives from 3 , we found the formation of isomerized conjugated ene-ynamide derivatives 4 unexpectedly and wish to report herein the results (Scheme 1).

Conjugated $^{5-7}$ or non-conjugated ${ }^{8}$ ene-ynamides are frequently used as synthetic intermediates, and as a key backbone of $\beta$-turn mimetics, tweezers-type host molecules, and a basic unit of molecular nanostructures. ${ }^{7}$

The triple bond-containing amide derivatives $\mathbf{3}$ were prepared from the corresponding ester $2 .{ }^{1}$ Hydrolysis of 2 in aq THF with $\mathrm{LiOH}$ and the following condensation with appropriate amines by using 1,1'-carbonyldiimidazole afforded 3 in moderate yields (61-82\%) and the results are summarized in Table 1. Initially, we tried many reaction

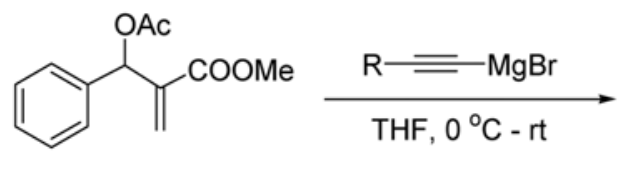

1<smiles>[R]C#C/C=C(/Cc1ccccc1)C(=O)N[R]</smiles>

Condition $\mathrm{A}\left(\mathrm{R}=\mathrm{CH}_{3}\right)$

LiHMDS (1.1 equiv)

THF, $0{ }^{\circ} \mathrm{C}-\mathrm{rt}, 5-11 \mathrm{~h}$

Condition $\mathrm{B}(\mathrm{R}=\mathrm{Ph})$

LiHMDS ( 0.3 equiv)

$\mathrm{Sc}(\mathrm{OTf})_{3}(0.1$ equiv)

$\mathrm{THF}, 0{ }^{\circ} \mathrm{C}-\mathrm{rt}, 30 \mathrm{~min}$ conditions including $\mathrm{I}_{2} / \mathrm{NaHCO}_{3}, \mathrm{I}_{2} / \mathrm{K}_{2} \mathrm{CO}_{3}, \quad \mathrm{I}_{2} / \mathrm{LiHMDS}$ (lithium bis(trimethylsilyl)amide) in order to synthesize the original target compounds, lactam derivatives. But, all the efforts resulted in failure for the synthesis of lactam derivatives. Thus, as a next choice, we examined the possibility for the lactamization in the presence of a strong base such as $\mathrm{NaH}, n$-BuLi, or LiHMDS without the aid of electrophile like iodine. However, we observed the unusual formation of conjugated ene-ynamide 4a in low yield from 3a instead of the desired lactam derivative when we used LiHMDS, unexpectedly.

Intrigued by the results we examined the isomerization conditions deeply and finally we could increase the yield of 4a up-to $60 \%$, under the influence of LiHMDS (1.1 equiv, THF). The structure of $\mathbf{4 a}$ was conformed by IR, ${ }^{1} \mathrm{H},{ }^{13} \mathrm{C}$, and mass spectroscopy. The synthesis of ene-ynamide is very important as mentioned above, ${ }^{5-7}$ thus we examined the isomerization reactions of $\mathbf{3 b}-\mathbf{e}$ and the results are summarized in Scheme 1 and in Table 1. As shown, the isomerization for 3a-c occurred effectively with the aid of LiHMDS (1.1 equiv.) in THF at room temperature. Use of less amounts of LiHMDS resulted in dramatic decrease in yields. The isomerization of $\mathbf{3 d}$ and $\mathbf{3 e}$ did not occur, however, under the same conditions (condition A). After devoting much efforts we finally found that the combination
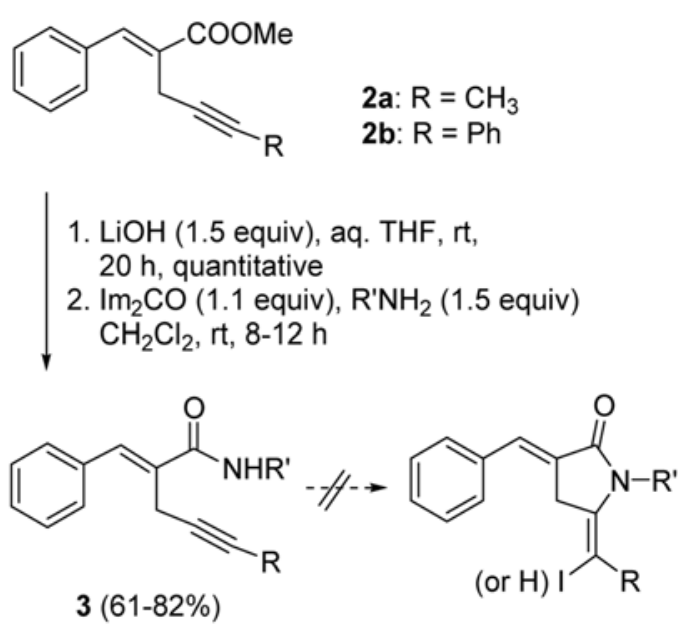

1. LiOH (1.5 equiv), aq. THF, rt, $20 \mathrm{~h}$, quantitative

2. $\mathrm{Im}_{2} \mathrm{CO}$ (1.1 equiv), $\mathrm{R}^{\prime} \mathrm{NH}_{2}$ (1.5 equiv)

(or $\mathrm{H})$

2a: $\mathrm{R}=\mathrm{CH}_{3}$

b: $\mathrm{R}=\mathrm{Ph}$

Scheme 1 
Table 1. Synthesis of conjugated ene-ynamides 4a-e

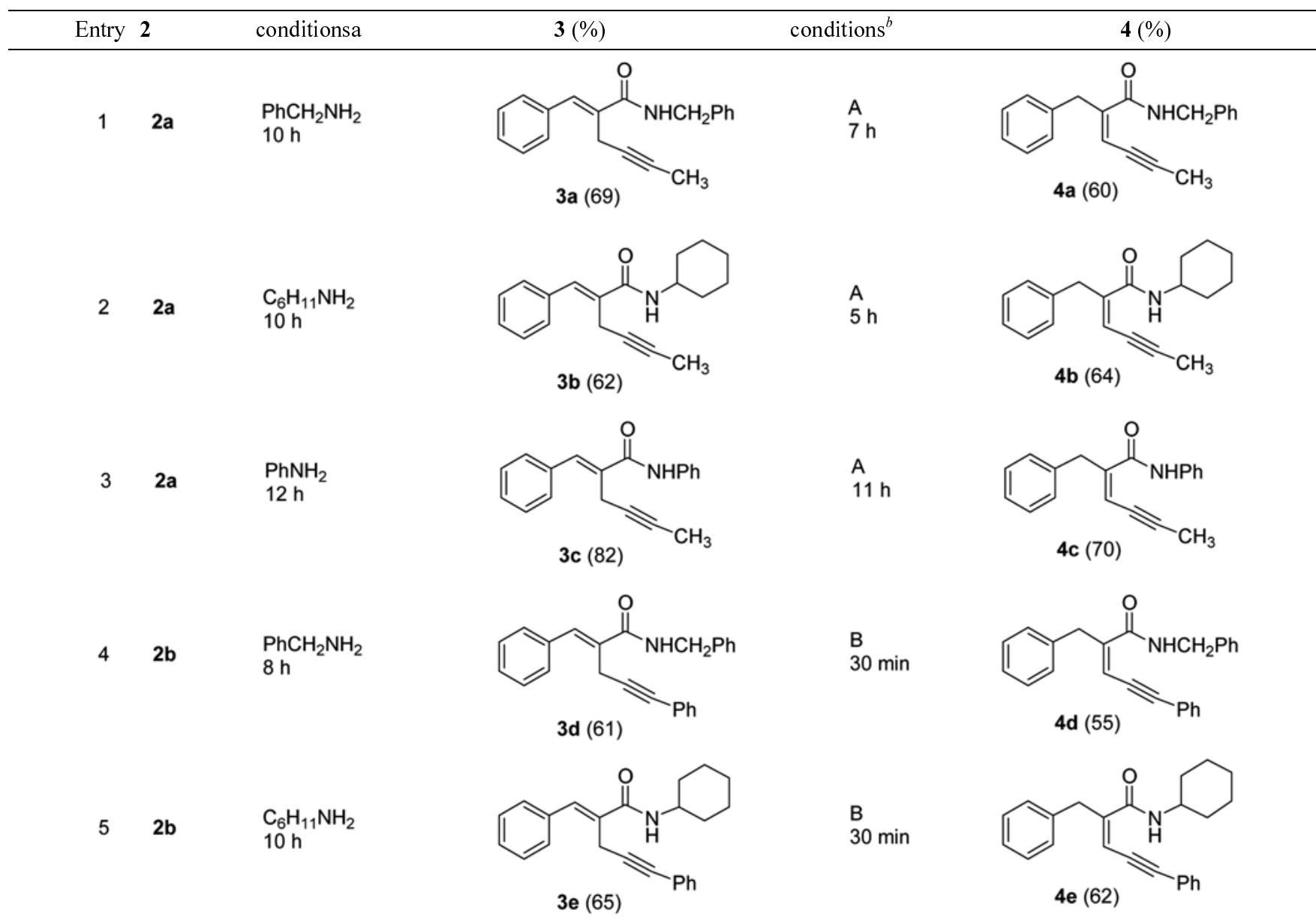

${ }^{a}$ (i) $\mathrm{LiOH}$ (1.5 equiv), aq THF, rt, $20 \mathrm{~h}$; (ii) $\operatorname{Im}_{2} \mathrm{CO}$ (1.1 equiv), amine (1.5 equiv), $\mathrm{CH}_{2} \mathrm{Cl}_{2}, \mathrm{rt}, 8-12$ h. ${ }^{b}$ Conditions A: LiHMDS (1.1 equiv), THF, $0{ }^{\circ} \mathrm{C}-\mathrm{rt}$; Conditions B: LiHMDS (0.3 equiv), Sc(OTf $)_{3}\left(0.1\right.$ equiv), THF, $0{ }^{\circ} \mathrm{C}-\mathrm{rt}$

of $\mathrm{Sc}(\mathrm{OTf})_{3}$ ( 0.1 equiv) and LiHMDS ( 0.3 equiv) could convert $\mathbf{3 d}$ and $\mathbf{3 e}$ into $\mathbf{4 d}$ and $\mathbf{4 e}$, respectively, in reasonable yields. ${ }^{9}$

The trials for the isomerization with the ester derivatives 2a and $\mathbf{2 b}$ failed completely under the similar reaction conditions. Remaining starting materials and small amounts of intractable mixtures were observed in the reaction mixtures. From the results we supposed that the amide proton of $\mathbf{3}$ might act in any way during the isomerization process. Although we could not explain the reaction mechanism exactly at this stage, we could propose the isomerization process tentatively as shown in Scheme 2. Initially, relatively acidic amide proton of $\mathbf{3}$ was deprotonated with LiHMDS. In the lithiated amide anion, there might be $\pi$-cation interaction ${ }^{10}$ between triple bond and lithium ion (vide infra) to form the six-membered stabilized intermediate (I). ${ }^{4,10 e, 11}$ Residual LiHMDS acts as an external base to deprotonate the proton at the allylic position (the acidity of the allylic proton might be increased also by the $\pi$ cation interaction) and caused the rearrangement as shown in Scheme 2 for 3a-c. For the phenyl-substituted substrates, $\mathbf{3 d}$ and $\mathbf{3 e}, \mathrm{Sc}(\mathrm{OTf})_{3}$ can replace the role of $\mathrm{Li}$ cation during the isomerization process although we could not explain exactly at this stage. The necessity of the acidic amide proton for the successful isomerization could be confirmed once again by the failure of $\mathbf{3 f}$, a tertiary amide, under the same conditions (Scheme 3 ).

The stereochemistry of the double bond of $4 \mathbf{a}-\mathbf{e}$ was thought to be as $(Z)$ based on the NOE experiments with $4 \mathbf{e}$ $\left(\mathrm{R}=\mathrm{Ph}, \mathrm{R}^{\prime}=\right.$ cyclohexyl, shown in Scheme 2$)$. Irradiation of the vinyl proton of $4 \mathrm{e}$ showed NOE increments of $2.3 \%$ and $0.6 \%$ of the benzylic protons and aromatic protons, respectively. The stereochemistry can also be explained well by using the proposed reaction mechanism in Scheme 2.

In addition, when we compared the relative energies of 3a and $4 \mathbf{a}$ by MM2 calculation, we found that $4 \mathbf{a}$ was more stable than $3 \mathbf{a}$ in about $2.5 \mathrm{kcal} / \mathrm{mol}$ presumably due to $\pi$ (triple bond)-H (amide proton) interaction. ${ }^{10}$ In the energyminimized conformations of $\mathbf{3 a}$ and $\mathbf{4 a}$, we could observe that the distance between the amide proton and the triple bond of $\mathbf{4 a}$ is closer than that of $\mathbf{3 a}$. We are currently investigating the detailed stabilization effect of $\pi$-cation and $\pi$-proton with B3LYP and the results will be published in due course.

In summary, we prepared some ene-ynamides starting from the Baylis-Hillman adducts. During the investigations, we found that $\pi$-cation interactions could increase the acidity of the nearby protons of triple bond of non-conjugated ene- 
<smiles>[R]C#CC/C(=C\c1ccccc1)C(=O)N[R]</smiles>

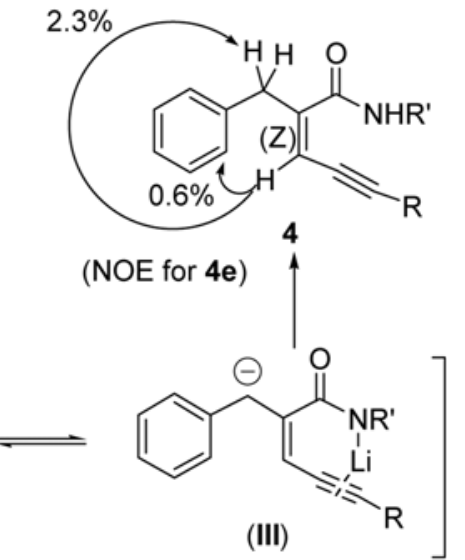

(I)<smiles></smiles><smiles>C#CC=C</smiles><smiles>[R]C#C[Al]([R])NC(=O)/C(C)=C/c1ccccc1</smiles>

Scheme 2

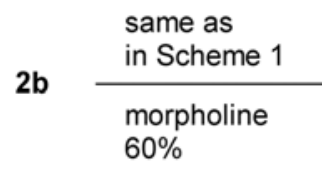<smiles>O=C(/C(=C/c1ccccc1)CC#Cc1ccccc1)N1CCOCC1</smiles>

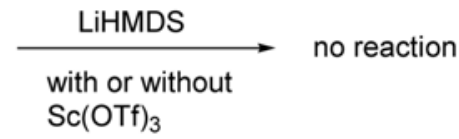

Scheme 3

ynamide and could make come true the isomerization into a more stable conjugated ene-ynamide form.

\section{Experimental Section}

Typical procedure for the amide derivatives 3: The corresponding methyl cinnamates $\mathbf{2}$ were made from the acetates of Baylis-Hillman adduct $\mathbf{1}$ as previously reported. ${ }^{1}$ Hydrolysis of $\mathbf{2}$ to the corresponding cinnamic acid derivatives was easily conducted with $\mathrm{LiOH}$ in aqueous THF (rt, $20 \mathrm{~h}$ ). After the hydrolysis, simple aqueous workup, and removal of solvent gave almost pure cinnamic acids and we used them without further purification step. A stirred solution of the cinnamic acid (prepared from 2a) (108 mg, $0.54 \mathrm{mmol}$ ) and 1,1'-carbonyldiimidazole (97 $\mathrm{mg}, 0.60$ $\mathrm{mmol})$ in dichloromethane $(3 \mathrm{~mL})$ was kept for $1 \mathrm{~h}$ at room temperature. To the reaction mixture benzylamine $(87 \mathrm{mg}$, $0.81 \mathrm{mmol}$ ) was added and stirred at room temperature for 9 h. After the usual workup and column chromatographic purification process (hexanes/EtOAc, $95: 5$ ) we obtained 3a as clear oil, $108 \mathrm{mg}(69 \%)$. The spectroscopic data of prepared compounds 3a-e are as follows.

Compound 3a: 69\%; oil; IR (neat) 3321, 1651, 1620, 1531 $\mathrm{cm}^{-1} ;{ }^{1} \mathrm{H} \mathrm{NMR}\left(\mathrm{CDCl}_{3}\right) \delta 1.76(\mathrm{t}, J=2.7 \mathrm{~Hz}, 3 \mathrm{H}), 3.31(\mathrm{q}, J$ $=2.7 \mathrm{~Hz}, 2 \mathrm{H}), 4.61(\mathrm{~d}, J=5.7 \mathrm{~Hz}, 2 \mathrm{H}), 6.72(\mathrm{br} \mathrm{s}, 1 \mathrm{H}), 7.26-$ $7.43(\mathrm{~m}, 10 \mathrm{H}), 7.55(\mathrm{~s}, 1 \mathrm{H})$.

Compound 3b: $62 \%$; white solid, mp $124-125^{\circ} \mathrm{C}$; IR (neat) $3275,2931,1616,1535 \mathrm{~cm}^{-1} ;{ }^{1} \mathrm{H}$ NMR $\left(\mathrm{CDCl}_{3}\right) \delta 1.22-1.77$ $(\mathrm{m}, 8 \mathrm{H}), 1.85(\mathrm{t}, J=2.4 \mathrm{~Hz}, 3 \mathrm{H}), 1.95-2.01(\mathrm{~m}, 2 \mathrm{H}), 3.27$ (q, $J$ $=2.4 \mathrm{~Hz}, 3 \mathrm{H}), 3.93-3.97(\mathrm{~m}, 1 \mathrm{H}), 6.37(\mathrm{~d}, J=6.9 \mathrm{~Hz}, 1 \mathrm{H})$, 7.29-7.42 (m, 5H), $7.49(\mathrm{~s}, 1 \mathrm{H}) ;{ }^{13} \mathrm{C} \mathrm{NMR}\left(\mathrm{CDCl}_{3}\right) \delta 3.78$, $18.48,24.76,25.87,33.10,48.47,76.23,78.55,128.36$, $128.69,129.38,131.68,135.70,135.80,167.27$.

Compound 3c: $82 \%$; white solid, mp $130-132{ }^{\circ} \mathrm{C}$; IR (neat) 3483, 1647, $1535 \mathrm{~cm}^{-1} ;{ }^{1} \mathrm{H}$ NMR $\left(\mathrm{CDCl}_{3}\right) \delta 1.91(\mathrm{t}, J$ $=2.7 \mathrm{~Hz}, 3 \mathrm{H}), 3.40(\mathrm{q}, J=2.7 \mathrm{~Hz}, 2 \mathrm{H}), 7.11-7.17(\mathrm{~m}, 1 \mathrm{H})$, 7.25-7.64 (m, 10H), 8.29 (br s, $1 \mathrm{H}) ;{ }^{13} \mathrm{C} \mathrm{NMR}\left(\mathrm{CDCl}_{3}\right) \delta$ $3.91,18.55,76.01,79.27,120.31,124.60,128.75,128.83$, 129.29, 129.47, 131.67, 135.44, 137.05, 138.36, 166.38 . Compound 3d: $61 \%$; white solid, $\mathrm{mp} 95-97{ }^{\circ} \mathrm{C}$; IR (neat) $3440,1647,1535 \mathrm{~cm}^{-1} ;{ }^{1} \mathrm{H}$ NMR $\left(\mathrm{CDCl}_{3}\right) \delta 3.61(\mathrm{~s}, 2 \mathrm{H})$, $4.63(\mathrm{~d}, J=5.7 \mathrm{~Hz}, 2 \mathrm{H}), 6.68$ (t, $J=5.7 \mathrm{~Hz}, 1 \mathrm{H}), 7.18-7.45$ $(\mathrm{m}, 15 \mathrm{H}), 7.60(\mathrm{~s}, 1 \mathrm{H}) ;{ }^{13} \mathrm{C} \mathrm{NMR}\left(\mathrm{CDCl}_{3}\right) \delta 18.96,44.19$, $82.82,86.15,122.85,127.51,127.80,128.20,128.25$, $128.45,128.61,128.77,129.22,130.73,131.67,135.28$, 136.33, 138.11, 167.78 .

Compound 3e: $65 \%$; white solid, mp $173-175{ }^{\circ} \mathrm{C}$; IR (neat) $3302,2931,2241,1620,1535 \mathrm{~cm}^{-1}$; ${ }^{1} \mathrm{H} \mathrm{NMR}\left(\mathrm{CDCl}_{3}\right) \delta 1.13-$ $1.76(\mathrm{~m}, 8 \mathrm{H}), 1.96-2.02(\mathrm{~m}, 2 \mathrm{H}), 3.57(\mathrm{~s}, 2 \mathrm{H}), 3.90-4.02(\mathrm{~m}$, $1 \mathrm{H}), 6.30(\mathrm{~d}, J=8.1 \mathrm{~Hz}, 1 \mathrm{H}), 7.28-7.48(\mathrm{~m}, 10 \mathrm{H}), 7.53(\mathrm{~s}$, $1 \mathrm{H}) ;{ }^{13} \mathrm{C} \mathrm{NMR}\left(\mathrm{CDCl}_{3}\right) \delta 19.22,24.84,25.81,33.19,48.67$, $82.86,86.57,123.23,128.43,128.52,128.56,128.79,129.42$, 131.34, 131.83, 135.70, 136.02, 167.18 .

Compound 3f: 60\%; oil; IR (neat) 1628, $1427,1115 \mathrm{~cm}^{-1}$; ${ }^{1} \mathrm{H} \mathrm{NMR}\left(\mathrm{CDCl}_{3}\right) \delta 3.66(\mathrm{~d}, J=0.9 \mathrm{~Hz}, 2 \mathrm{H}), 3.69(\mathrm{t}, J=4.2$ $\mathrm{Hz}, 4 \mathrm{H}), 3.78(\mathrm{t}, J=4.2 \mathrm{~Hz}, 4 \mathrm{H}), 6.59(\mathrm{~s}, 1 \mathrm{H}), 7.25-7.45(\mathrm{~m}$, $10 \mathrm{H}) ;{ }^{13} \mathrm{C} \mathrm{NMR}\left(\mathrm{CDCl}_{3}\right) \delta 20.66,67.08(\mathrm{br}), 82.26,85.55$, $129.14,128.12,128.15,128.36,128.62,128.87,130.37$, $131.23,131.52,134.83,170.76$.

Typical procedure for the isomerization of 3 a to 4 a: To a stirred solution of 3a (101 mg, $0.35 \mathrm{mmol})$ in dry THF (1 $\mathrm{mL})$ was added LiHMDS $(0.39 \mathrm{~mL}, 0.39 \mathrm{mmol}, 1.0 \mathrm{~mol}$ solution in THF) slowly at $0{ }^{\circ} \mathrm{C}$ under nitrogen atmosphere and the reaction mixture was stirred further $7 \mathrm{~h}$ at room temperature. After the usual workup and column chromatographic purification process (hexanes/EtOAc, 95:5) we obtained $4 \mathbf{a}$ as a white solid, $61 \mathrm{mg}(60 \%)$. The spectroscopic data of prepared compounds $4 \mathbf{a}-\mathbf{c}$ are as follows. 
Compound 4a: $60 \%$; white solid, mp $78-80{ }^{\circ} \mathrm{C}$; IR (neat) $3386,2924,2217,1689,1651,1527 \mathrm{~cm}^{-1} ;{ }^{1} \mathrm{H} \mathrm{NMR}\left(\mathrm{CDCl}_{3}\right)$ $\delta 1.74(\mathrm{~d}, J=2.7 \mathrm{~Hz}, 3 \mathrm{H}), 3.74(\mathrm{~s}, 2 \mathrm{H}), 4.51(\mathrm{~d}, J=5.4 \mathrm{~Hz}$, $2 \mathrm{H})$, 5.66-5.69 (m, 1H), 7.17-7.35 (m, $11 \mathrm{H}) ;{ }^{13} \mathrm{C}$ NMR $\left(\mathrm{CDCl}_{3}\right) \delta 4.53,39.77,44.11,76.86,96.37,112.17,126.68$, $127.65,128.11,128.75,128.88,129.45,138.19,138.82$, 145.85, 166.16; Mass (70 eV) $\mathrm{m} / \mathrm{z}$ (rel. intensity) 77 (18), 91 (100), 115 (25), 153 (20), 198 (18), $289\left(\mathrm{M}^{+}, 30\right)$.

Compound 4b: 64\%; white solid, mp $105-107{ }^{\circ} \mathrm{C}$; IR (neat) $3290,2935,2222,1631,1543 \mathrm{~cm}^{-1} ;{ }^{1} \mathrm{H}$ NMR $\left(\mathrm{CDCl}_{3}\right) \delta 1.10-1.71(\mathrm{~m}, 8 \mathrm{H}), 1.85-1.92(\mathrm{~m}, 2 \mathrm{H}), 2.00(\mathrm{~d}, J=$ $2.7 \mathrm{~Hz}, 3 \mathrm{H}), 3.69(\mathrm{~s}, 2 \mathrm{H}), 3.81-3.94(\mathrm{~m}, 1 \mathrm{H}), 5.59-5.63(\mathrm{~m}$, 1H), 6.91 (br s, $1 \mathrm{H}), 7.16-7.30(\mathrm{~m}, 5 \mathrm{H}) ;{ }^{13} \mathrm{C} \mathrm{NMR}\left(\mathrm{CDCl}_{3}\right) \delta$ 4.75, 24.69, 25.86, 33.03, 39.73, 48.11, 77.01, 95.50, 111.35, $126.59,128.69,129.43,138.94,146.78,165.43$.

Compound 4c: $70 \%$; white solid, mp $119-121{ }^{\circ} \mathrm{C}$; IR (neat) $2221,1651,1597 \mathrm{~cm}^{-1} ;{ }^{1} \mathrm{H}$ NMR $\left(\mathrm{CDCl}_{3}\right) \delta 2.08(\mathrm{~d}, J$ $=2.4 \mathrm{~Hz}, 3 \mathrm{H}), 4.01(\mathrm{~s}, 2 \mathrm{H}), 6.70(\mathrm{q}, J=2.4 \mathrm{~Hz}, 1 \mathrm{H}), 7.02-$ $7.08(\mathrm{~m}, 1 \mathrm{H}), 7.22-7.39(\mathrm{~m}, 10 \mathrm{H}) ;{ }^{13} \mathrm{C} \mathrm{NMR}\left(\mathrm{CDCl}_{3}\right) \delta 1.24$, $35.72,77.43,97.80,119.12,120.08,124.61,127.43,128.63$, $129.15,129.40,137.87,138.19,143.50,165.27$.

Typical procedure for the isomerization of $3 \mathrm{~d}$ to $4 \mathrm{~d}$ : To a stirred solution of $\mathbf{3 d}(105 \mathrm{mg}, 0.3 \mathrm{mmol})$ in dry THF (1 $\mathrm{mL})$ was added $\mathrm{Sc}(\mathrm{OTf})_{3}(15 \mathrm{mg}, 0.03 \mathrm{mmol})$ and LiHMDS $(0.1 \mathrm{~mL}, 0.1 \mathrm{mmol}, 1.0 \mathrm{~mol}$ solution in THF) successively at $0{ }^{\circ} \mathrm{C}$ under nitrogen atmosphere and the reaction mixture was stirred further $30 \mathrm{~min}$ at room temperature. After the usual workup and column chromatographic purification process (hexanes/EtOAc, $95: 5$ ) we obtained $\mathbf{4 d}$ as clear oil, $58 \mathrm{mg}(55 \%)$. The spectroscopic data of prepared compounds $\mathbf{4 d}$ and $\mathbf{4 e}$ are as follows.

Compound 4d: $55 \%$; white solid, $\mathrm{mp} 100-102{ }^{\circ} \mathrm{C}$; IR (neat) $2195,1693,1655 \mathrm{~cm}^{-1} ;{ }^{1} \mathrm{H}$ NMR $\left(\mathrm{CDCl}_{3}\right) \delta 3.82(\mathrm{~d}, J$ $=1.5 \mathrm{~Hz}, 2 \mathrm{H}), 4.55(\mathrm{~d}, J=5.4 \mathrm{~Hz}, 2 \mathrm{H}), 5.93(\mathrm{t}, J=1.5 \mathrm{~Hz}$, $1 \mathrm{H})$, 6.99-7.03 (m, 2H), 7.18-7.34 (m, 14H); ${ }^{13} \mathrm{C}$ NMR $\left(\mathrm{CDCl}_{3}\right) \delta 40.10,44.26,85.76,98.70,111.44,126.84$, $127.72,128.30,128.60,128.86,128.97,129.21,129.58$, $131.60,138.05,138.56,146.90,166.13$.

Compound 4e: $62 \%$; white solid, mp $127-130{ }^{\circ} \mathrm{C}$; ${ }^{1} \mathrm{H}$ NMR $\left(\mathrm{CDCl}_{3}\right) \delta 1.03-1.70(\mathrm{~m}, 8 \mathrm{H}), 1.89-1.95(\mathrm{~m}, 2 \mathrm{H}), 3.76$ $(\mathrm{d}, J=1.5 \mathrm{~Hz}, 2 \mathrm{H}), 3.82-3.94(\mathrm{~m}, 1 \mathrm{H}), 5.86(\mathrm{t}, J=1.5 \mathrm{~Hz}$, $1 \mathrm{H}), 6.74(\mathrm{~d}, J=6.6 \mathrm{~Hz}, 1 \mathrm{H}), 7.20-7.42(\mathrm{~m}, 10 \mathrm{H}) ;{ }^{13} \mathrm{C} \mathrm{NMR}$ $\left(\mathrm{CDCl}_{3}\right) \delta 24.89,25.78,33.23,48.58,85.90,97.85,110.55$, $122.56,126.77,128.77,128.76,128.80,129.21,129.53$, $131.55,138.61,147.90,165.47$.

Acknowledgments. This work was supported by the grant (R-05-2003-000-10042-0) from the Basic Research Program of the Korea Science and Engineering Foundation (Now controlled under the authority of Korea Research Foundation). Spectroscopic data was obtained from the Korea Basic Science Institute, Gwangju branch.

\section{References and Notes}

1. Gowrisankar, S.; Lee, K. Y.; Lee, C. G.; Kim, J. N. Tetrahedron Lett. 2004, 45, 6141.
2. Gowrisankar, S.; Lee, M. J.; Lee, S.-k.; Kim, J. N. Bull. Korean Chem. Soc. 2004, 25, 1963.

3. For the electrophile-assisted synthesis of lactam derivatives, see (a) Knapp, S.; Levorse, A. T. J. Org. Chem. 1988, 53, 4006. (b) Takahata, H.; Takamatsu, T.; Chen, Y.-S.; Ohkubo, N.; Yamazaki, T.; Momose, T.; Date, T. J. Org. Chem. 1990, 55, 3792. (c) Kurth, M. J.; Bloom, S. H. J. Org. Chem. 1989, 54, 411. (d) Takahata, H.; Takamatsu, T.; Yamazaki, T. J. Org. Chem. 1989, 54, 4812.

4. For the activation of triple bond in the lactamization, see (a) Koseki, Y.; Kusano, S.; Nagasaka, T. Tetrahedron Lett. 1998, 39, 3517. (b) Koseki, Y.; Kusano, S.; Ichi, D.; Yoshida, K.; Nagasaka, T. Tetrahedron 2000, 56, 8855 .

5. For the synthesis and usefulness of ene-ynamides as synthetic intermediates, see (a) Saito, S.; Chounan, Y.; Nogami, T.; Fukushi, T.; Tsuboya, N.; Yamada, Y.; Kitahara, H.; Yamamoto, Y. J. Org. Chem. 2000, 65, 5350. (b) Cherry, K.; Thibonnet, J.; Duchene, A.; Parrain, J.-L.; Abarbri, M. Tetrahedron Lett. 2004, 45, 2063. (c) Fiandanese, V.; Babudri, F.; Marchese, G.; Punzi, A. Tetrahedron 2002, 58, 9547. (d) Kundu, N. G.; Khan, M. W. Tetrahedron 2000, 56, 4777. (e) Kundu, N. G.; Khan, M. W. Tetrahedron Lett. 1997, 38, 6937. (f) Reich, S. H.; Melnick, M.; Pino, M. J.; Fuhry, M. A. M.; Trippe, A. J.; Appelt, K.; Davis II, J. F.; Wu, B.-W.; Musick, L. J. Med. Chem. 1996, 39, 2781. (g) Kundu, N. G.; Khan, M. W.; Mukhopadhyay, R. Tetrahedron 1999, 55, 12361. (h) Balavoine, F.; Madec, D.; Mioskowski, C. Tetrahedron Lett. 1999, 40, 8351. (i) Sashida, H.; Kawamukai, A. Synthesis 1999, 1145. (j) Sakamoto, T.; An-Naka, M.; Kondo, Y.; Yamanaka, H. Chem. Pharm. Bull. 1986, 34, 2754. (k) Eberbach, W.; Laber, N. Tetrahedron Lett. 1992, 33, 61. (l) Alami, M.; Crousse, B.; Linstrumelle, G. Tetrahedron Lett. 1995, 36, 3687. (m) Shen, Y; Gao, S. J. Fluorine Chem. 1993, 61, 273.

6. For the biologically active ene-ynamides, see (a) Crombie, L.; Horsham, M. A.; Blade, R. J. Tetrahedron Lett. 1987, 28, 4879. (b) Bouchain, G.; Leit, S.; Frechette, S.; Khalil, E. A.; Lavoie, R.; Moradei, O.; Woo, S. H.; Fournel, M.; Yan, P. T.; Kalita, A.; Trachy-Bourget, M.-C.; Beaulieu, C.; Li, Z.; Robert, M.-F.; MacLeod, A. R.; Besterman, J. M.; Delorme, D. J. Med. Chem. 2003, 46, 820

7. For the other usefulness of ene-ynamides, see (a) Kemp, D. S.; Li, Z. Q. Tetrahedron Lett. 1995, 36, 4175. (b) Nguyen, T.-Q.; Martel, R.; Avouris, P.; Bushey, M. L.; Brus, L.; Nuckolls, C. J. Am. Chem. Soc. 2004, 126, 5234. (c) Yagi, S.; Kitayama, H.; Takagishi, T. J. Chem. Soc., Perkin Trans. 1 2000, 925.

8. For the synthesis and usefulness of non-conjugated ene-ynamides, see (a) Huang, J.; Xiong, H.; Hsung, R. P.; Rameshkumar, C.; Mulder, J. A.; Grebe, T. P. Org. Lett. 2002, 4, 2417. (b) Marion, F.; Coulomb, J.; Courillon, C.; Fensterbank, L.; Malacria, M. Org. Lett. 2004, 6, 1509. (c) Saito, N.; Sato, Y.; Mori, M. Org. Lett. 2002, 4, 803 .

9. For the $\mathrm{Sc}(\mathrm{OTf})_{3}$ complexation, see (a) Fukuzumi, S.; Inada, O.; Satoh, N.; Suenobu, T.; Imahori, H. J. Am. Chem. Soc. 2002, 67, 9181. (b) Kennedy, J. W. J.; Hall, D. G. J. Org. Chem. 2004, 69, 4412.

10. For cation- $\pi$ interactions, see: (a) Ma, J. C.; Dougherty, D. A. Chem. Rev. 1997, 97, 1303. (b) Arnecke, R.; Bohmer, V.; Cacciapaglia, R.; Cort, A. D.; Mandolini, L. Tetrahedron 1997, 53, 4901. (c) Roelens, S.; Torriti, R. J. Am. Chem. Soc. 1998, 120, 12443. (d) Dvornikovs, V.; Smithrud, D. B. J. Org. Chem. 2002, 67, 2160. (e) Gokel, G. W.; Barbour, L. J.; Ferdani, R.; Hu, J. Acc. Chem. Res. 2002, 35, 878.

11. During the evaluation process of this paper one of the reviewers suggested the NMR monitoring experiments. However we could not carry out the experiments due to the presence of many intractable side products in the reaction mixtures. For such NMR experiments of $\pi$-complexation, see Nilsson, K.; Ullenius, C.; Krause, N. J. Am. Chem. Soc. 1996, 118, 4194 and for the alkali metal cation- $\pi$ interactions including triple bond, see the reference 10 (e). 